\title{
Proceedings
}

\section{Tendencies of Fire Development in the Forests of Ukraine ${ }^{\dagger}$}

\author{
Yevhen Melnyk * and Vladimir Voron *
}

Citation: Melnyk, Y.; Voron, V. Tendencies of Fires Development in the Forests of Ukraine. Environ. Sci. Proc. 2021, 3, 106. https://doi.org/ 10.3390/IECF2020-08064

Published: 13 November 2020

Publisher's Note: MDPI stays neutral with regard to jurisdictional claims in published maps and institutional affiliations.

Copyright: (C) 2020 by the authors. Licensee MDPI, Basel, Switzerland. This article is an open access article distributed under the terms and conditions of the Creative Commons Attribution (CC BY) license (http://creativecommons.org/licenses /by/4.0/).
Ukrainian Research Institute of Forestry and Forest Melioration Ukrainian Research Institute of Forestry and Forest Melioration Named after G. M. Vysotsky, Laboratory of Forest Ecology, 61024 Kharkiv, Ukraine

* Correspondence: Wudckij@bigmir.net (Y.M.); 52corvus@gmail.com (V.V.)

+ Presented at the 1st International Electronic Conference on Forests - Forests for a Better Future: Sustainability, Innovation, Interdisciplinarity, 15-30 November 2020; Available online: https://iecf2020.sciforum.net.

\begin{abstract}
Preservation and increase of forest area are necessary conditions for the biosphere functioning. Forest ecosystems in most parts of the world are affected by fires. According to the latest data, the forest fire situation has become complicated in Ukraine, and this issue requires ongoing investigation. The aim of the study was to analyse the dynamics of wildfires in Ukrainian forests over recent decades and to assess the complex indicator of wildfire occurrence in various forest management zones and administrative regions. The average annual complex indicator of fire occurrence, in terms of wildfire number and burned area, was studied in detail in the forests of various administrative regions and forest management zones in Ukraine from 1998 to 2017. The results show that fire occurrence in both the number and area of fires can vary significantly in various forest management zones. There is a very noticeable difference in these indicators in some administrative regions within a particular forest management zone. The data show that the number of forest fires depends not only on the natural and climatic conditions of such regions, but also on anthropogenic factors.
\end{abstract}

Keywords: fire tendencies; natural fire danger; administrative region; forest management zone; relative fire occurrence

\section{Introduction}

Most regions of the world are constantly affected by forest fires. A significant part of them is large fires, which lead to devastating consequences [1]. Forest fire issues remain quite acute for many countries, especially in the context of global warming [2]. For example, up to 130 thousand forest fires were registered in the United States annually in the 2000s, and the total burned area was up to 3 million hectares [3]. From 10 to 40 thousand wildfires occurred on average each year in the Russian Federation, with a total burned area of 120 million hectares [4]. Between 2000 and 2007, 156 and 210 thousand fires were recorded in Portugal and Spain, respectively [5]. During the same period, more than 30,000 forest fires were recorded in Ukraine, and 34 thousand hectares of forests were damaged by the fire $[6,7]$.

According to many researchers [8-11], the main cause of forest fires is a human impact.

\section{Materials and Methods}

To achieve the goal of the study, data were collected from various sources on forest fires in Ukraine from 1998 to 2017 [12-15]. This took into account the fact that forest fire databases cover the forests of the entire forest fund of Ukraine with the area of 10.4 million hectares as well as a part of the territory making 7.6 million hectares of forests or $73 \%$ that are forests being in constant use of state forestry enterprises subordinated to the State Forest Resources Agency of Ukraine (SFRAU) [12-14]. 
Changes in the average annual fire number and burned area were analysed between 1998 and 2017. We applied the method of mathematical and statistical analysis using computer application programs. According to the methodology of Soyuzdiprolishosp [16], the actual average annual forest fire occurrence by the number and area of fires per 1 thousand hectares of the total area was determined for different forest management zones and administrative regions in Ukraine during 2007-2017. The boundaries of forest management zones are confined to the borders of administrative regions [17].

\section{Results and Discussion}

Comparison of the numbers and areas of fires in Ukrainian forests showed significant fluctuations for these indicators for the 20 years from 1998 to 2017. The number of fires in Ukraine in some years ranged from 1113 to 7036, while it was from 806 to 5264 incidents in the forests managed by the State Forest Resources Agency of Ukraine. The difference was even greater for the area damaged by the fires. The wildfire area was in the range of 0.4-16.6 thousand ha for all forests of Ukraine and in the range of 0.2-13.8 thousand ha in the forests of the State Forest Resources Agency of Ukraine. Therefore, the maximum annual number of fires exceeds the minimum one by seven times, and the maximum burned area is almost 70 times the minimum one.

The fires in the forests managed by the State Forest Resources Agency of Ukraine made from $58 \%$ to $90 \%$ by number and from $18 \%$ to $94 \%$ by area from the total wildfires in Ukraine over the years (Figure 1).

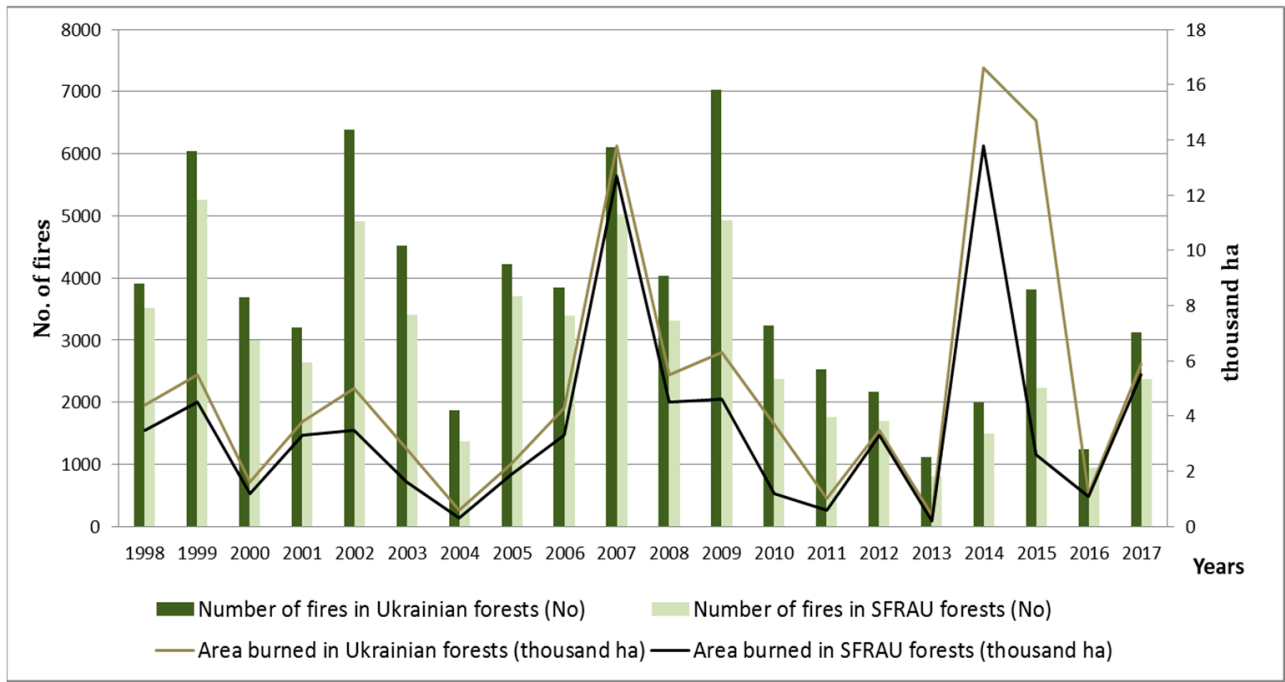

Figure 1. Fire dynamics in all Ukrainian forests and those managed by the State Forest Resources Agency of Ukraine (SFRAU) during 1998-2017.

Very high wildfire numbers in 2002, 2007, and 2009 significantly exceeded the average annual value of the entire period. The largest exceedances of the average annual area were recorded in 2007, 2014, and 2015. Thus, the maxima in the fire number and burned area in some years may not coincide. Such a negative fire situation, especially regarding the burned area, has been significantly deteriorated due to the increase fires in Donetsk and Luhansk regions since 2014. Comparison of average annual data for 10-year periods showed that in recent years the average annual burned area has increased from 4.4 thousand hectares (1998-2007) to 5.9 thousand hectares (2008-2017) in all Ukrainian forests and from 3.6 thousand hectares to 3.7 thousand hectares in the forests managed by the State Forest Resources Agency of Ukraine. However, the average annual number of fires decreased from 4379 to 3032 in all Ukrainian forests and from 3621 to 2190 in the forests managed by the State Forest Resources Agency of Ukraine. 
An essential part of the analysis of the fire situation in all Ukrainian forests is to determine the spatial trends of fires in different forest management zones and administrative regions during 2007-2017 (Table 1, Figure 2).

Table 1. Average annual wildfire occurrence in forest management zones in Ukrainian forest fund from 2007 to 2017.

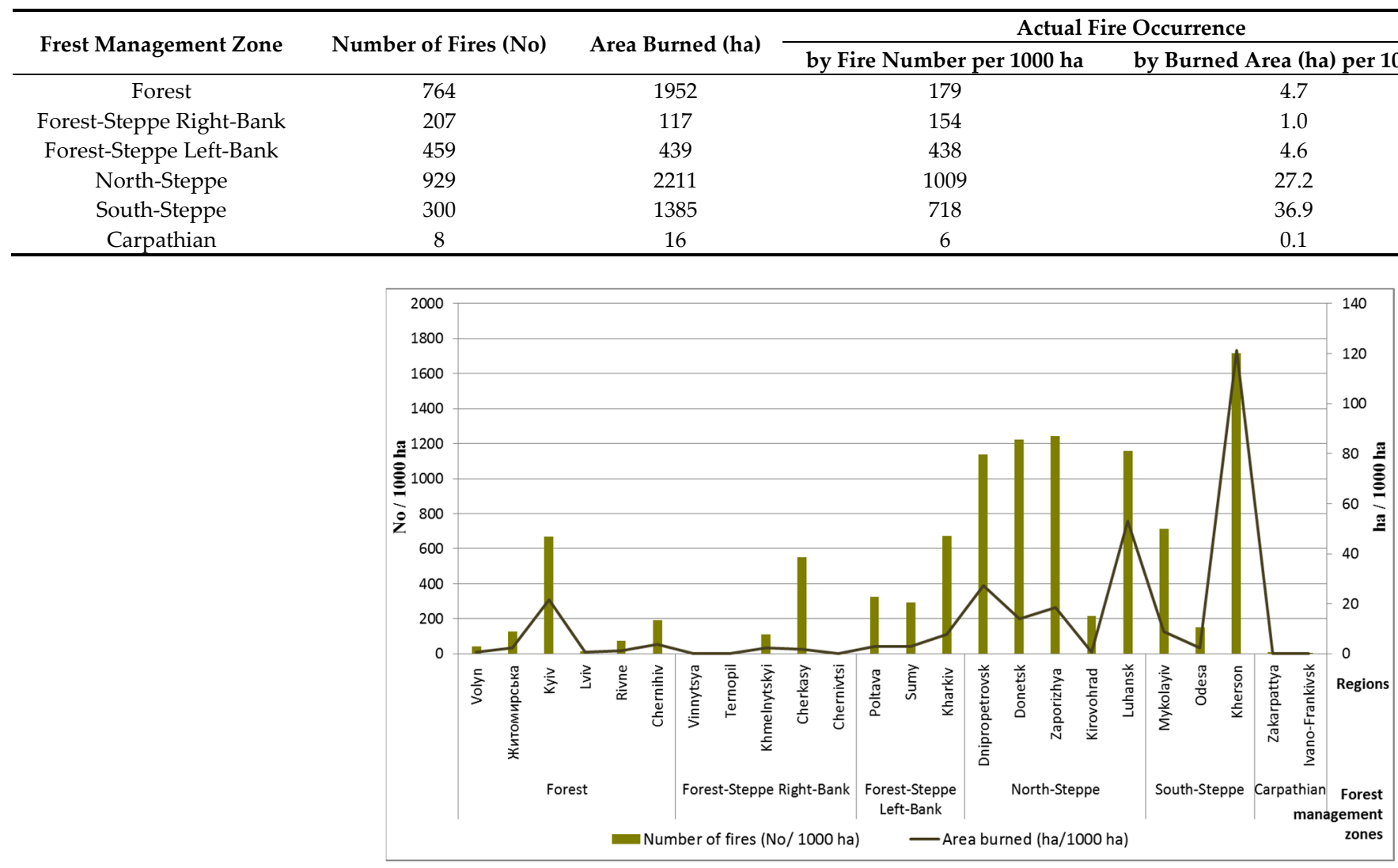

Figure 2. Average annual wildfire occurrence by fire number and burned area in all forests of Ukrainian regions from 2007 to 2017.

The largest average number of fires -929 incidents per year - was recorded in the North-Steppe forest management zone, while in the Forest zone, the number was 764. The average number of fires per year was 460 in the Forest-Steppe Left-Bank forest management zone, 300 in the South-Steppe zone, 207.4 in the Forest-Steppe Right-Bank zone, and 7.7 in the Carpathian forest management zone. The order relative to the average annual area of forests damaged by fire was somewhat different. The highest value was recorded in the North-Steppe forest management zone-2.2 thousand hectares per year, and further in descending order: Forest zone-1.9 thousand hectares per year, South-Steppe zone-1.4 thousand hectares per year, Forest-Steppe Left-Bank forest management zone- 0.4 thousand hectares per year, Forest-Steppe Right-Bank forest management zone -0.1 thousand hectares per year, and Carpathian forest management zone-only 0.02 thousand hectares per year.

The actual fire occurrence, i.e., the relative number and burned area of wildfires per 1000 ha of forest area, was also analysed. The actual fire occurrence in terms of fire number varied considerably from six incidents per 1000 ha (Carpathian forest management zone) to 1009 incidents per 1000 ha (North-Steppe forest management zone). The indicator was very high in the South-Steppe forest management zone: 718 fires per 1000 hectares. For other zones, the average values ranged from 154 to 438 fires per 1000 hectares.

For the Carpathians, the minimum actual occurrence was recorded also in terms of area (0.1 ha per 1000 ha). However, the maximum value (36.9 ha per 1000 ha) was registered in the South-Steppe forest management zone. Very high value, 27.2 hectares per 
1000 hectares, was recorded in the North-Steppe zone. In all other forest management zones, the indicator was several times lower, ranging between 1 and 5 hectares per 1000 hectares. Therefore, the differences in wildfire number and burned area per 1000 hectares can reach dozens of times for the Steppe zone, which has the driest natural conditions, and some other natural zones.

The distribution of precipitation within Ukraine shows a change from excessive moisture in the north and northwest to a moisture deficit in the south and southeast [15]. The average temperature, for example, in July in Polissya (forest zone in Ukraine) is from +15 to $+19{ }^{\circ} \mathrm{C}$, while in Forest-Steppe it ranges from +18 to $+22^{\circ} \mathrm{C}$. In Steppe, the average temperature of the month varies from +20 to $+24{ }^{\circ} \mathrm{C}$ from west to east. The number of days with temperatures above $15^{\circ} \mathrm{C}$ is also increasing from the Forest to the Steppe zone. If in the Forest zone (Polissya) the number of those days per year is 95-110, then in the Forest-Steppe Left-Bank zone it is 110-130, and in the South-Steppe zone, 125-145 [6].

Zonal features of forest fire occurrence depend not only on the climatic conditions of natural zones, but also on anthropogenic factors [8-11]. We analysed fire occurrence in specific administrative regions with similar climatic conditions within various Ukrainian forest management zones. The results showed that fire hazard could be several tens of times higher in densely populated regions than in other neighboring areas. For example, the fire occurrence in the Forest zone (Figure 2) was the highest in the Kyiv region, both by number and burned area. There is such a big metropolis as the capital with a population of 2.9 million in the region. In the Forest-Steppe Left-Bank zone, the highest rates were recorded in the Kharkiv region with Kharkiv, the large metropolis of 1.4 million inhabitants. In the Steppe zone, where most regions are also densely populated, fire occurrence indicators in terms of both number and area are the most critical due to particularly arid climatic conditions.

\section{Conclusions}

The number and area of wildfires in the Ukrainian forests can vary considerably from year to year and far exceed the average annual values of the entire long-term period.

The actual fire occurrence varies significantly in the fire number and burned area per 1000 hectares across forest management zones of Ukraine. This difference is especially noticeable between the forest management zones of the Steppe, which is the driest zone of Ukraine, and all other natural zones. Forest management zones can be arranged from the maximum to the minimum value of the actual wildfire occurrence by the number in the following order: North-Steppe, Forest, Forest-Steppe Left-Bank, South-Steppe, Forest-Steppe Right-Bank, and Carpathian. There is a slightly different order for wildfire occurrence by burned area: North-Steppe, South-Steppe, Forest-Steppe Left-Bank, Forest-Steppe Right-Bank, and Carpathian.

There is a great difference in actual fire occurrence between some administrative regions within the same forest management zone.

The fire occurrence may vary significantly in the administrative regions of some forest management zones due to both natural conditions and anthropogenic specificities. For example, in the Forest and Forest-Steppe forest management zones, the highest rates are characteristic of the most densely populated areas in Kyiv and Kharkiv regions.

\section{References}

1. Goldammer, J.G. Vegetation Fires and Global Change: Challenges for Concerted International Action; A white paper directed to the United Nations and international organizations; Kessel Publ House: Remagen-oberwinter, Germany, 2013 ; p. 400.

2. Shvydenko, A.Z.; Shchepashchenko, D.G. Climate change and forest fires in Russia. Lesovedenie 2013, 5, 50-61.

3. Fire Management Global Assessment. 2006. Available online: http://www.fao.org/3/a0969e/a0969e00.htm (accessed on 23 September 2019).

4. Andreev, Y.A.; Amelchugova, S.V. General patterns of fires in the forest and settlements. In Proceedings of the All-Russian Conference fires in forest ecosystems of Siberia, Krasnoyarsk, Russia, 17-19 September 2008; pp. 35-37. 
5. Forest Fires in Europe 2007; Report No 8; European Commission, Joint Research Centre, Institute for Environment and Sustainability. $\quad$ European Communities. 2008; 82p. Available online: https://effis.jrc.ec.europa.eu/media/cms_page_media/40/01-forest-fires-in-europe-2007.pdf (accessed on 8 August 2020).

6. National Report on the State of Technogenic and Natural Safety in Ukraine in 2014-2017. Available online: http://undicz.dsns.gov.ua/ua/Nacionalna-dopovid-pro-stan-tehnogennoyi-ta-prirodnoyi-bezpeki-v-Ukrayini.html (accessed on 11 August 2020).

7. Yavorovsky, P.P. Wild fires and the system of fire barriers construction in the Ukraine forests. Sci. Her. NULES Ukr. Ser. For. Decor. Gard. 2014, 198, 62-71.

8. Evangeliou, N.; Balkanski, Y.; Cozic, A.; Hao, W.M.; Mouillot, F.; Thonicke, K.; Paugam, R.; Zibtsev, S.; Mousseau, T.A.; Wang, R. Fire evolution in the radioactive forests of Ukraine and Belarus: Future risks for the population and the environment. Ecol. Monogr. 2015, 85, 49-72.

9. Zibtsev, S.V.; Borsuk, O.A. Protecting forests from fires in the world and in Ukraine the challenges of the XXI century and prospects for development. For. Landsc. Gard. 2012, $1 . \quad$ Available online: http://journals.nubip.edu.ua/index.php/Lis/article/view/9630 (accessed on 4 August 2020).

10. Kuzyk, A.D. Forest firedanger assessment on weather conditions. Sci. Bull. UNFU 2011, 21, 74-81.

11. Andreev, Y.A. Influence of Anthropogenic and Natural Factors on the Occurrence of Fires in Forests and Settlements; FGU VNIIPO Emergencies Ministry of Russia: Moscow, Russia, 2003; p. 45.

12. Public Report of the State Forest Resources Agency of Ukraine 2016, 2017, 2018, 2019. Available online: http://dklg.kmu.gov.ua/forest/control/uk/publish/article?art_id=166328\&cat_id=113360 (accessed on 1 August 2020).

13. Natsionalna Dopovid 2001-2017. The State Emergency Service of Ukraine. Available online: https://www.dsns.gov.ua/ua/Analitichniy-oglyad-stanu-tehnogennoyi-ta-prirodnoyi-bezpeki-v--Ukrayini-za-2015-rik.html (accessed on 14 February 2020).

14. Zibtsev, S.V.; Soshenskyi, O.M.; Gumeniuk, V.V.; Koren, V.A. Long term dynamic of forest fires in Ukraine. Ukr. J. For. Wood Sci. 2019, 10, 27-40.

15. Kuzyk, A.D.; Kucheriavyj, V.P. Influence of meteorological factors on xerofillization of the forest environment and fire occurrence. For. For. Melior. 2009, 116, 238-244.

16. Mokeev, G.A. The Impact of Natural and Economic Conditions on the Fireability of Forests and Their Protection from Fires; Forest Industry, Moscow, Russia, 1965, p. 324.

17. Pasternak, P.S.; Kiselevskiy, R.G.; Fedets, I.F.; Medvedev, L.A. Forestry zoning of the Ukrainian SSR. For. For. Melior. 1980, 56, 3-16. 